\title{
Micro-scale Experiments in the Increasingly Fashionable Laboratory in High Schools
}

\author{
Sheila Ruiz Botella*, Susana Ibáñez* \\ Institute of Advanced Materials (INAM), Center for Innovation in Advanced Chemistry (ORFEO-CINQA), Universitat Jaume I, Castellon, \\ Spain
}

Email address:

sbotella@qio.uji.es(S. R. Botella),maella@uji.es(S. Ibáñez)

${ }^{*}$ Corresponding author

\section{To cite this article:}

Sheila Ruiz Botella, Susana Ibáñez. Micro-scale Experiments in the Increasingly Fashionable Laboratory in High Schools. Science Journal of Education. Vol. 8, No. 5, 2020, pp. 128-132. doi: 10.11648/j.sjedu.20200805.13

Received: August 26, 2020; Accepted: September 15, 2020; Published: September 28, 2020

\begin{abstract}
Objective: Experimental activities in laboratories are an important part in teaching and learning chemistry. Nevertheless, its implementation may be limited by the lack of material, instrument and above all the risk involved in doing so in the laboratory. Not only because of the cost of the reagents, but also because of the safety of the students in the classroom. That is why the use of simple micro-scale experiments turns out to be a benefit for the teaching of chemistry to high school students. Methods: Micro-scale practices also facilitate the implantation of constructivist laboratory practices, presented as small investigations, displacing traditional laboratory practices. The design of practices from a constructivist approach allows working all or some aspects of the scientific method. A constructivist methodology will increase the student's interest in the subject and bring them closer to the scientific method, which will provoke the development of their observation capacity, the ability to make hypotheses, the skill in the design of experimental setups, discussing results, drawing conclusions and relating empirical data to theoretical principles. In contrast, traditional practices are usually prescription-type practices completely lack the scientific method. Since there are numerous difficulties in implementing practices with a constructivist methodology, both methods may be considered according to the space, time, and materials possibilities. Conclusion: The micro-scale experiments is useful for different reasons: reduces chemical use by promoting waste reduction of the source, save money, improves safety, may be carry out in class and sometimes at home, decreases experiment time and student carry out the experiments by themselves which is important for a significant learning.
\end{abstract}

Keywords: Micro-scale, Constructivism, High School Student, Chemistry Experiments

\section{Introduction}

For the last years, a micro-scale chemistry has become important as a part of chemistry that develops experiences for having a low cost, risk of danger in the manipulation of laboratory material and easy work in the classroom. [1-8] And so much this favors a didactic innovation on the part of the teacher and the development of the creativity of the pupil when participating in the construction of the same of the work of laboratory. [9] One of them could be the use of materials low cost, meaning homemade materials, recycled materials and others that can be purchased at affordable prices in conventional shops or through the internet. This could partially alleviate the shortage of laboratory equipment and make it easy to take it to carry out a greater number of experimental works. [10-16] Science teaching has been enriched with advances in cognitive psychology and epistemology, giving rise to the constructivist paradigm. [17-22] Micro-scale practices also facilitate the implantation of constructivist laboratory practices, presented as small investigations, displacing traditional laboratory practices. The design of practices from a constructivist approach allows working all or some aspects of the scientific method. A constructivist methodology will increase the student's interest in the subject and bring them closer to the scientific method, which will provoke the development of their observation capacity, the ability to make hypotheses, the skill in the design of experimental setups, discussing results, drawing conclusions and relating empirical data to theoretical 
principles. In contrast, traditional practices are usually prescription-type practices completely lack the scientific method. Since there are numerous difficulties in implementing practices with a constructivist methodology, both methods may be considered according to the space, time, and materials possibilities.

The use of these materials to present the science to students (and, to the public, in general) is not new: already appears in Gaston's first publications Tissandier, [23] in whose "RecreacionesCientífícas" (around 1880) shows a large collection of physics experiments and of chemistry that can be executed using "cups, bottles..., and other insignificant objects that all the world can find at hand." The availability of the necessary reagents to carry these experiments is also another factor in especially if we limit ourselves to the substances that we found in the homemade medicine cabinet (alcohol, oxygenated water or iodine), or to which we can obtain from some food products (vinegar, oil, bicarbonate, salt, sugar, red cabbage, fruits, etc.), from cleaning products for the home (salfuman, concentrated vinegar, caustic soda, bleach, ammonia cleaner, laundry bleach, etc.), of products that can be purchased in hypermarkets and hardware (batteries, steel wool, galvanized screws, gas for refilling lighters, fertilizers, fungicides, products to control the $\mathrm{pH}$ of the pool water, etc.) and pharmacies (30\% oxygenated water, tablets of iodide potassium, of vitamin C, etc.). [24-27]

It is impossible to forget the health crisis that Covid-19 has provoked. Due to this pandemic, many classes have been suspended, which has led to move classes or laboratories from school to our homes. Microscale chemistry help us front this difficult situation since most of these practices may be carried out at home. The practices that have been designed and described below have been designed to develop students 'skills using easily accessible resources. The proposed experiments can be used as practical activities of a qualitative or quantitative nature. For example, chemical reactions are endothermic or exothermic, as the reaction of decomposition, oxidation-reduction, combustion or acid-base or neutralization.

Decomposition reaction is a chemical reaction in which a substance separates into two, or more, less complex substances, usually by the action of heat, light and/or electricity. The oxidation-reduction reaction is one in which the oxidation states of an atom are changed. These reactions are characterized by the transfer of electrons between chemical species. Combustion reaction is a rapid oxidation reaction, which is usually accompanied by heat and light. Acid-base or neutralization reaction, to understand what happens in this type of reaction we must understand that it is an acid and a base. Arrehenius formulated the first definitions of acid and base from the theory of ionic dissociation. An acid is any substance that, in aqueous solution, dissociates generating protons, $\mathrm{H}+$ and a base is any substance that in aqueous solution dissociates generating hydroxides. But as we measure the degree of acidity or basicity of a substance. By means of the well-known $\mathrm{pH}$ scale. The $\mathrm{pH}$ scale allows us to know the degree of acidity or basicity of a given substance.
The scale goes from 1 to 14 . If the $\mathrm{pH}$ is less than 7 , the substance is acidic. If it is equal to 7 the substance is neutral. If it is greater than 7 the substance is basic. The acid-base indicators have a different coloring depending on the $\mathrm{pH}$ medium. A neutralization reaction is one in which an acid reacts with a base, forming a salt and water, obtaining a $\mathrm{pH}$ of 7 .

And as a conclusion, during a chemical reaction heat is emitted or absorbed, usually in the form of heat, light and/or electricity. A reaction in which energy is released is called exothermic and if energy is absorbed it is endothermic.

\section{Materials and Experiments}

The aim of this practice is to understand the concept of chemical reaction by studying various types of reactions by means of simple and micro-scale tests; analyzing the capacity of one compound for oxidize or reduce and the acid or basic nature of them, measuring and understanding the $\mathrm{pH}$ scale and interpreting acid-base reactions and their reversibility. The materials, substances and reagents are shown in Table 1.

Table 1. Description of the material and reagents used in practice.

\begin{tabular}{|c|c|}
\hline \multicolumn{2}{|l|}{ Materials } \\
\hline latex gloves & plastic-coated paper \\
\hline safety glasses & stirring rod \\
\hline laboratory notebook & plastic pipette \\
\hline 2 small bottles & $\mathrm{pH}$ paper \\
\hline \multicolumn{2}{|l|}{4 small beakers } \\
\hline \multicolumn{2}{|l|}{ Substances and Reagents } \\
\hline Water & coke \\
\hline $\mathrm{CuSO}_{4}$ solution & bleach \\
\hline aluminum foil & vinegar \\
\hline $\mathrm{NaHCO}_{3}$ and $\mathrm{HCl}$ solutions $(0.5 \mathrm{M})$ & saliva \\
\hline red cabbage extract (indicator) & $\mathrm{NaCl}$ \\
\hline
\end{tabular}

Students can do these practices as if it were a game. First, it would be interesting if they would make a prediction of what they think is happening (type of reaction, expected colour changes). Later, students may check it out and contrast their observations with their prediction. Finally, they should try to find out exactly how and why this has happened.

\section{Result}

Let us start with Test 1.0 (Figure 1), it explains how $\mathrm{Cu}$ is obtained instead of $\mathrm{Cu}_{2} \mathrm{O}$ in the reaction of $\mathrm{CuSO}_{4}$ with $\mathrm{Al}$. The steps are the following:

1. Dissolve the $\mathrm{CuSO}_{4}$ in water (one solution for the whole class).

2. Follow the steps outlined in the plastic file attached to the practice (Figure 2).

3. Write down your observations and explain what information they give you.

Test 1.0, experiment to redox reaction of aluminum foil with salt of cupper (II) 

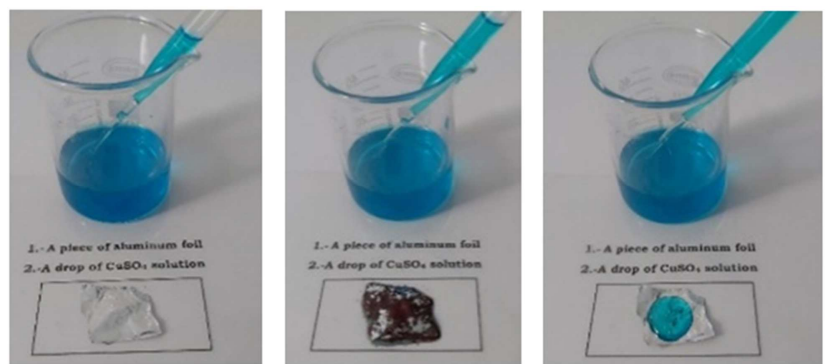

Figure 1. Before (left), during the process (middle) and after (right) making the experiments of Test 1.0.

If we add a copper (II) sulphate solution to a piece of aluminum foil, nothing happens, but if we add sodium chloride, a chemical reaction of displacement and redox takes place, in which the aluminum oxidizes and the copper is reduced. In addition, another reaction takes place in which hydrogen is displaced from the water, releasing the hydrogen gas in the form of bubbles. Sodium chloride and copper sulphate act as catalysts.

Let us starts with test 1.1 (Figure 4). This test might be done at home. Some of the questions that help to students' predictions are the following: which is the acidic or basic nature of bicarbonate? And the acidulant?

1. Dissolve the bicarbonate in water (one solution for the whole class).

2. Dissolve the acidulant (one solution for the entire class).

3. Follow the steps outlined in the plastic file attached to the practice (Figure 3).

4. Write down your observations and explain what information they give you.

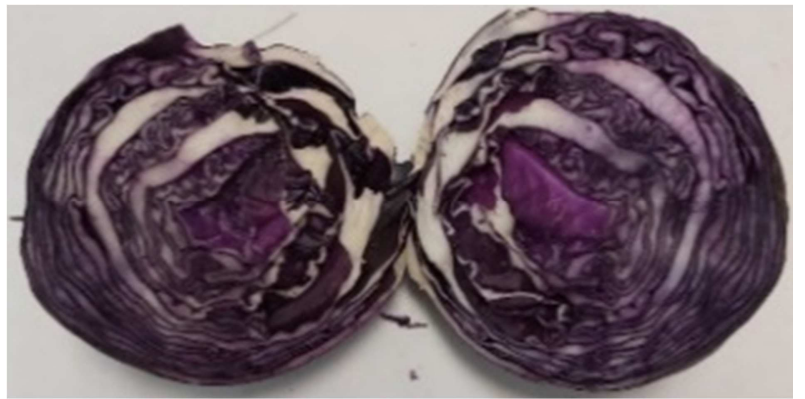

Figure 2. Picture of red cabbage.

The red cabbage extract is a natural indicator as it contains a substance called anthocyanin. Anthocyanins are water-soluble pigments found in the vacuoles of plant cells that give red, purple, or blue color to leaves, flowers and fruits.

Anthocyanins are found in many dark fruits (such as blue and black raspberries, blackberries, cherries, plums, blueberries, blue and black grapes) and many vegetables. According to the $\mathrm{pH}$, its color is given by the hydroxyl groups of the phenolic rings and the benzopyril, so that in an acidic medium (with a $\mathrm{pH}$ of less than 5) it takes on a reddish coloring, while in an alkaline medium (with a $\mathrm{pH}$ of more than 7) it takes on a purple coloring. [28]

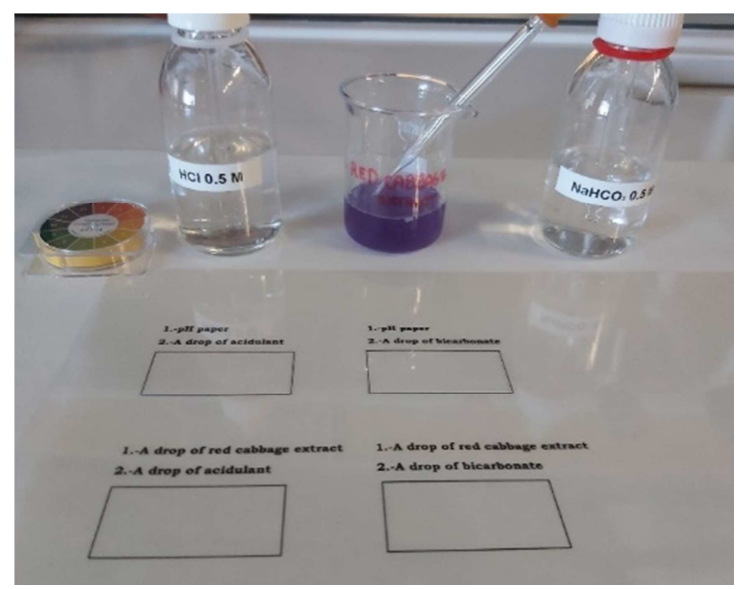

Figure 3. Materials and substances with reagents from de Test 1.1.

Test 1.1, experiments to determine the color of acidity or basicity of red cabbage extract
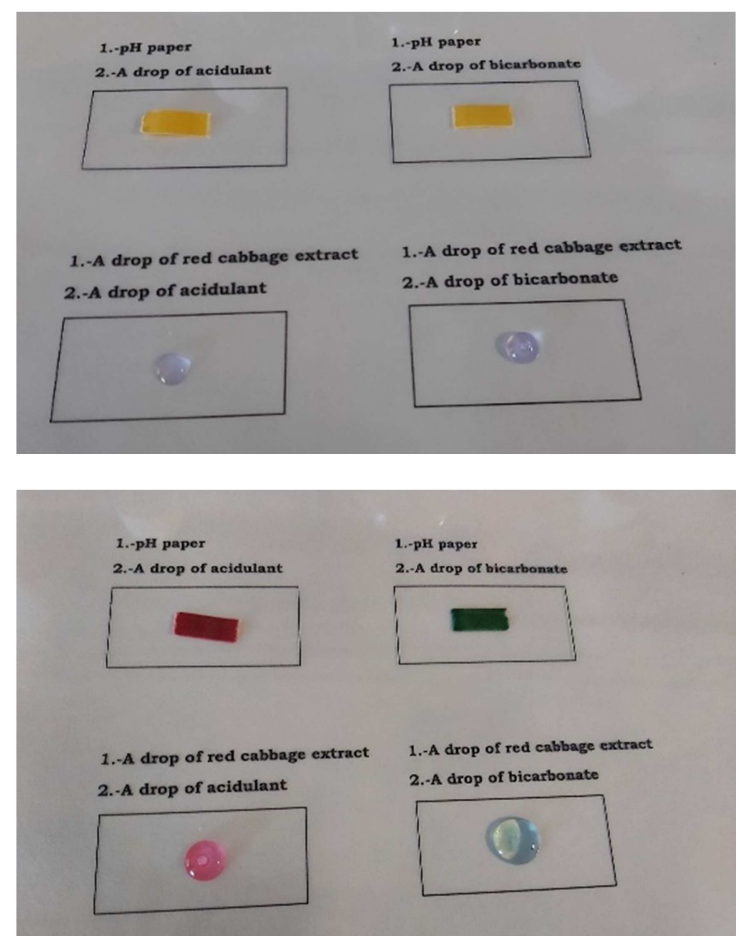

Figure 4. Before(up) and after(down) making the experiments of Test 1.1.

It is observed that the red cabbage extract in acid $\mathrm{pH}$ is pink color and in basic $\mathrm{pH}$ is blue. They can be compared with the colors observed by adding a drop of $\mathrm{HCl}$ (acidulant) or $\mathrm{NaHCO}_{3}$ (bicarbonate) on the $\mathrm{pH}$ paper, which is our reference.

In the test 1.2 (see Figure 5) and test 1.3 (see Figure 6) the question and procedure for students is: which is the $\mathrm{pH}$ of bleach, vinegar, coke, or saliva? Are they acid or bases? Students can add any other solution to the list.

1. Follow the steps outline for test 1.2 and 1.3.

2. Write down your observations and explain what information they give you.

3. What $\mathrm{pH}$ has the solutions and mixtures? Use the $\mathrm{pH}$ paper to be more precise. 
Test 1.2, experiments to determine the acidity or basicity of bleach or vinegar.
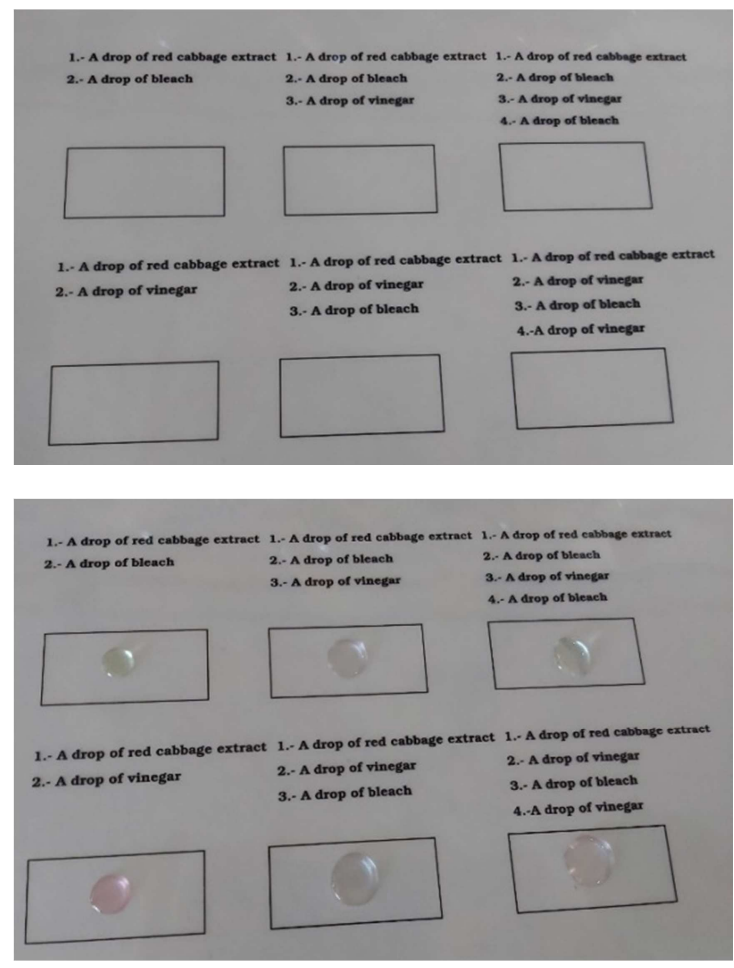

Figure 5. Before (up) and after (down) making the experiments of Test 1.2.

In Test 1.2 (see Figure 5), in all cases a drop of red cabbage extract is added first. In the case of the top row, a bleach drop is added first, and the drop becomes a little light blue. Then in step 3 a drop of vinegar is added, and it becomes more colourless and in step 4 another drops of bleach, it becomes bluer. In summary we have gone from a basic light $\mathrm{pH}$ to a neutral and then back to basic.

In the case that after adding the first drop of red cabbage extract a drop of vinegar is added (see figure 5, the bottom row) the drop turns pink, because is an acidic substance, the next step is to add a drop of bleach, the drop becomes more colourless and finally a drop of vinegar the drop turns pink again. In short, we have gone from an acidic $\mathrm{pH}$ to a neutral $\mathrm{pH}$ and then acid again, showing the reversible nature of acid-base reaction.

Test 1.3 , experiments to determine the acidity or basicity of coke or saliva.

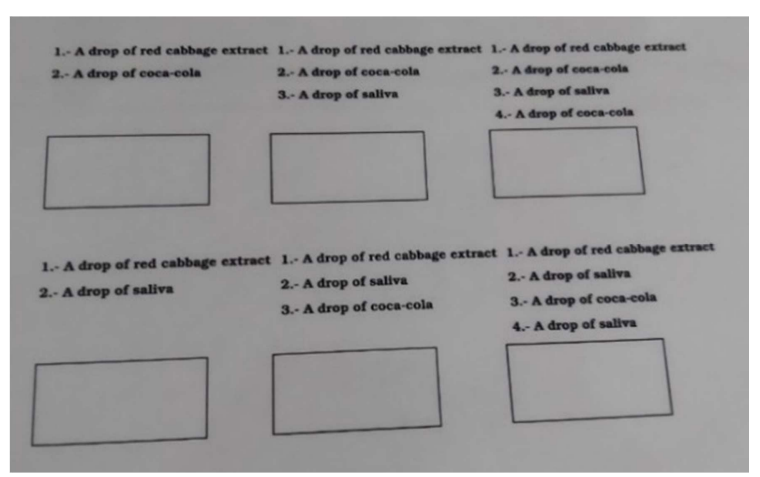

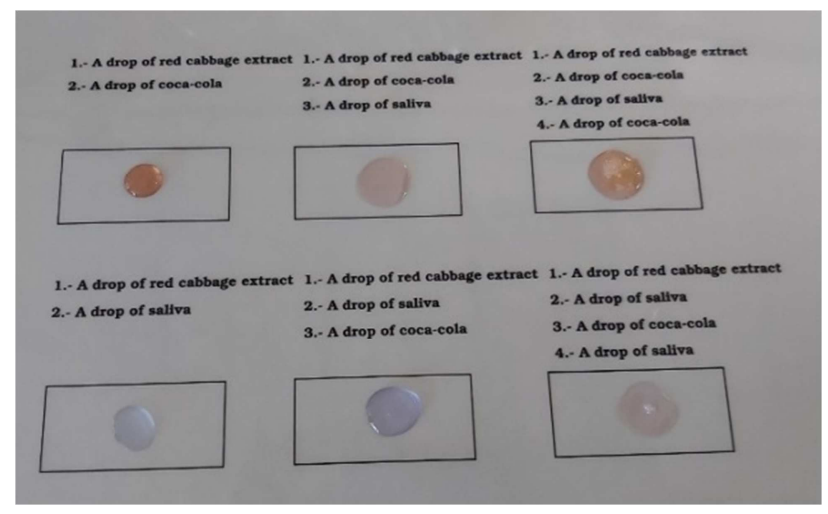

Figure 6. Before (up) and after (down) making the experiments of Test 1.3.

In test 1.3 , in all cases a drop of red cabbage extract is added first. In the case of the top row, a coke drop is added first, and the drop becomes a dark red, a little brown. Then in step 3 a drop of saliva is added, and it becomes more colourless and in step 4 another drops of coke, it becomes dark red. In summary we have gone from an acidic $\mathrm{pH}$ to a neutral $\mathrm{pH}$ and then acid again.

In the case that after adding the first drop of red cabbage extract a drop of saliva is added (see Figure 6, the row below) the drop turns blue, because, we are at a basic $\mathrm{pH}$, the next step is to add a drop of coke, the drop becomes more colourless and finally a drop of saliva the drop turns clear blue again. In short, we have gone from a basic $\mathrm{pH}$ to a neutral $\mathrm{pH}$ and then basic again.

As can be seen in these texts, depending on the nature of the agent you add, the drop of the natural extract, i.e. in our case of red cabbage, will change colour from pink to blue depending on its $\mathrm{pH}$.

\section{Conclusion}

The micro-scale experiments is useful for different reasons: reduces chemical use by promoting waste reduction of the source, save money, improves safety, may be carry out in class and sometimes at home, decreases experiment time and student carry out the experiments by themselves which is important for a significant learning. But above all, the main advantage of working with these materials is that the teachers and our students end up understanding that it is not necessary to have much material to expose the principles of chemistry. We have the possibility to learn the principles of this subject by using not only small quantities of reagents but also everyday tools and substances. Chemistry is around us, therefore, it is our responsibility make it easy.

\section{Acknowledgements}

We gratefully acknowledge financial support from the Universitat Jaume I (UJI-A2017-02).

\section{References}

[1] P. Schwarz, Weighing and weights in microscale science experimentation, Journal of Science Education 5 (2) (2004) 112. 
[2] V. Wiskamp, P. Schwarz, Multilevel Microscale Titration, Journal of Science Education 8 (1) (2007) 55-57.

[3] P. Schwarz, Determination of the hardness of water by a microscaled EDTA titration, Journal of Science Education 6 (2) (2005) 51.

[4] A. Tomás-Serrano, J. Hurtado-Perez, Experimentos cuantitativos de química, con materiales de bajo coste, para alumnos de Bachillerato, An. Quím. 115 (5) (2019) 421-428.

[5] F. J. Arnáiz, R. M. Pike, Microescala en los laboratorios de química. Una revolución imparable, An. Quím. 3 (1999) 45-51.

[6] F. J. Arnáiz, Química en microescala en los laboratorios de Química Inorgánica y Organometálica, Educación Química 16 (4) (2005) 504-509.

[7] R. C. C. Duarte, M. G. T. C. Ribeiro, A. A. S. C. Machado, Reaction scale and green chemistry: Microscale or macroscale, which is greener? Journal of Chemical Education 94 (9) (2017) 1255-1264.

[8] B. Worley, E. M. Villa, J. M. Gun, B. Mattson, Visualizing dissolution, ion mobility, and precipitation through a low-cost, rapid-reaction activity introducing microscale precipitation chemistry, Journal of Chemical Education 96 (5) (2019) 951-954.

[9] M. Rodríguez, Química en cantidades ínfimas III Jornada Enseñanza de la Química Valencia, 2009.

[10] G. Pinto, Didáctica de la química y vida cotidiana, An. Quím. 1 (2003) 44-52.

[11] A. González, C. Urzúa, Experimentos químicos de bajo coste: un aporte desde la microescala, Revista Eureka sobre Enseñanza y Divulgación de las Ciencias 9 (3) (2012) 401-409.

[12] M. B. Sére, La enseñanza en el laboratorio. Qué podemos aprender en términos de conocimiento práctico y de actitudes hacia la ciencia?, Enseñanza de las ciencias 20 (3) (2002) 357-368.

[13] O. Barberá, P. Valdés, El trabajo práctico en la enseñanza de las ciencias: una revisión, Enseñanza de las ciencias 14 (3) (1996) 365-379.

[14] M. R. Prat, C. Ballesteros, G. M. Lescano, La previa: una estrategia de aprendizaje en las prácticas de química, Educación Química, 29 (4) (2018) 18-27.

[15] S. Esteban, El botiquín en casa: una forma de aprender química, Revista Eureka sobre Enseñanza y Divulgación de las Ciencias 1 (3) (2017) 224-232.

[16] A. Tomás, R. García, Determinación de la constante de Avogadro mediante un experimento de electrólisis realizado con productos de bajo coste, An. Quím. 113 (2017) 47-53.

[17] J. Piaget, The Child's Conception of the World, Rowman \& Little field 2007.

[18] J. Piaget, The Principles of Genetic Epistemology, Routledge 1997.

[19] D. P. Ausubel, Educational Psychology: A Cognitive view, Holt, Rinehalt \& Winston, New York, 1968.

[20] R. M. Gagné, The Conditions of Learning, Holt, Rinehart \& Winston 1970.

[21] J. S. Bruner, The Process of Education, Harvard University Press 1977.

[22] E. R. Scerri, Philosophical confusion in chemical education research, Journal of Chemical Education 80 (5) (2003) 468-474.

[23] G. Tissandier, Recreaciones científicas. La física y la química sin aparatos ni laboratorio y solo por los juegos de la infancia, Alta Fulla (1900) 1981.

[24] G. Schwedt, Experimentos con productos de supermercado. Merceología química, Editorial Acribia 2009.

[25] J. Haan, Ciencia en tus manos, Encuentro Editorial, S. A. Plaza \& Janés. Tusquets 1991.

[26] J. Corominas Viñas Revista Eureka sobre Enseñanza y Divulgación de las Ciencias 8 (2017) 454-459.

[27] S. Heredia, Experiencias sorprendentes de química con indicadores de $\mathrm{pH}$ caseros, Revista Eureka sobre Enseñanza y Divulgación de las Ciencias 3 (1) (2006) 89-103.

[28] O. Val-Castillo, Estudio de sustancias naturales como indicadores de $\mathrm{pH}$. Una propuesta didáctica, An. Quím. 116 (2020) 88-98. 